\title{
VARIABILITY OF PARTICULATE MATTER PM10 CONCENTRATION IN SOSNOWIEC, POLAND, DEPENDING ON THE TYPE OF ATMOSPHERIC CIRCULATION
}

\author{
ADAMEK, A. - ZIERNICKA-WOJTASZEK, A. \\ Department of Ecology, Climatology and Air Protection, Faculty of Environmental \\ Engineering and Land Surveying, University of Agriculture in Kraków \\ al. Mickiewicza 24/28, 30-059 Kraków, Poland \\ e-mail: adama.adamek@gmail.com; a.ziernicka-wojtaszek@ur.krakow.pl
}

(Received $13^{\text {th }}$ Jun 2017; accepted $26^{\text {th }}$ Sep 2017)

\begin{abstract}
The aim of the study was to evaluate variation in PM10 concentrations in the city of Sosnowiec, Poland in relation to the type of atmospheric circulation. Data on the average daily concentration of PM10 during the heating season in the years 2013-2015 were obtained from the Sosnowiec monitoring station on Lubelska Street, belonging to the Air Quality Monitoring System run by the Voivodeship Inspectorate for Environmental Protection in Katowice. PM10 concentrations were found to be higher in anticyclonic conditions, on average $55 \mu \mathrm{g} / \mathrm{m}^{3}$, as compared to $45 \mu \mathrm{g} / \mathrm{m}^{3}$ in cyclonic conditions. The highest risk of exceeding the permissible PM10 concentration is observed in Ka, Sa, SWa and $\mathrm{Ca}$ conditions. The results of this study may be used to predict high PM10 concentrations and exceedances of permissible levels based on synoptic forecasts.
\end{abstract}

Keywords: air quality, particulate matter, heating seasons, air masses advection, baric system

\section{Introduction}

Air pollution is one of the most important environmental issues. Poland has exceptionally poor air quality, which is largely due to excessive PM10 particulate matter concentrations. According to the European Environment Agency, Poland ranks second in Europe in terms of the daily concentration of PM10 in the air (European Environment Agency, 2016). Analysis of spatial variations in pollutant concentrations within Poland indicates that they are higher in the southern part of the country, especially in the Silesia and in Małopolska regions. Particularly high air pollution occurs in the Upper Silesian Agglomeration, which is linked to the industrial character of this area, dating back many years, as well as its high population density (WIOŚ Katowice, 2016). Air pollution negatively affects human health. Particulates in the air can increase the incidence of respiratory and cardiovascular diseases and the risk of cancer, and affects life expectancy. Periods with high concentrations of pollutants, known as smog, are particularly dangerous. The level of pollutants in the air is affected not only by current emissions associated with the municipal and housing sector, transport, and industry, but also by local and regional meteorological conditions, such as air temperature, precipitation, wind velocity, and the type of atmospheric circulation (Majewski, 2005; Czarnecka and Kalbarczyk, 2008; Leśniok and Caputa, 2009, Leśniok et al. 2010). The focus of the present work was the concentration of PM10 particulate matter in the city of Sosnowiec, located within the Zagłębie Dąbrowskie (coal basin), which is part of the Silesian Voivodship (region). In terms of the number of inhabitants, Sosnowiec is the third largest city in Silesia and fifteenth largest in the whole country. The aim of the present study was to assess the variability of PM10 concentrations in the area of Sosnowiec, depending on the type of atmospheric circulation. 


\section{Materials and methods}

The basis for the study consisted in the data on average daily concentrations of PM10 particulate matter in the months of the heating seasons, within the period of 2013-2015. Exceedances of the permissible concentrations of PM10 in the air (Official Journal of Laws 2012 item 1031) are closely linked to the combustion of fossil fuels of poor quality in home furnaces and fireplaces (WIOŚ Katowice 2014). Air pollution is characterized by seasonality (Majewski, 2007; Czarnecka and Nidzgorska-Lencewicz, 2010). The concentrations analysed were recorded at the monitoring station in Sosnowiec on Lubelska street (Fig. 1), belonging to the Air Quality Monitoring System run by the Regional Inspectorate for Environmental Protection in Katowice.

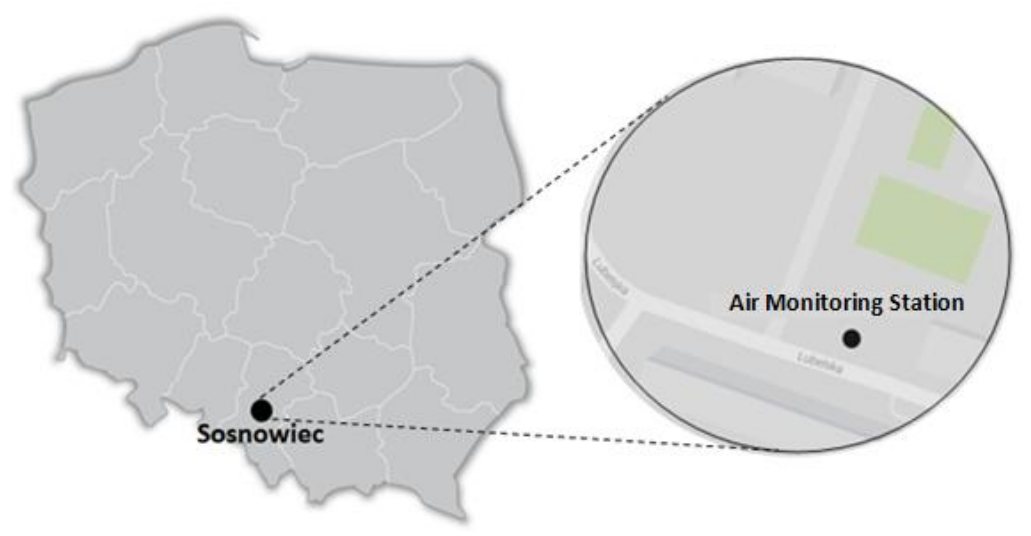

Figure 1. Location of the air quality monitoring station

The calendar of circulation types developed by Niedźwiedź (Niedźwiedź, 1981) was used to analyse the concentrations of PM10 particulate matter depending on the type of atmospheric circulation. For each of the 21 types of atmospheric circulation, the incidence and the mean, maximum and minimum concentrations of PM10 were recorded during the heating season months, i.e. January, February, March, April, October, November and December in the period of 2013-2015, for a total number of 636 days. The overall incidence of each atmospheric circulation type and their frequency of occurrence on days with excessive PM10 levels have been presented.

\section{Research results}

Using the data from the measurement station belonging to the Regional Inspectorate for Environmental Protection in Katowice, the average daily concentration of PM10 particulate matter was computed and assigned to each day of the heating season. The arithmetic mean of the PM10 concentration reached $50.9 \mu \mathrm{g} / \mathrm{m}^{3}$, the standard deviation was $29.6 \mu \mathrm{g} / \mathrm{m}^{3}$, and the variation coefficient was $58.0 \%$, which means that the PM10 concentration varied considerably during the study period. The analysis showed that the permissible levels were exceeded 252 times, which represents $40.0 \%$ of the total period under consideration (Fig. 2). 


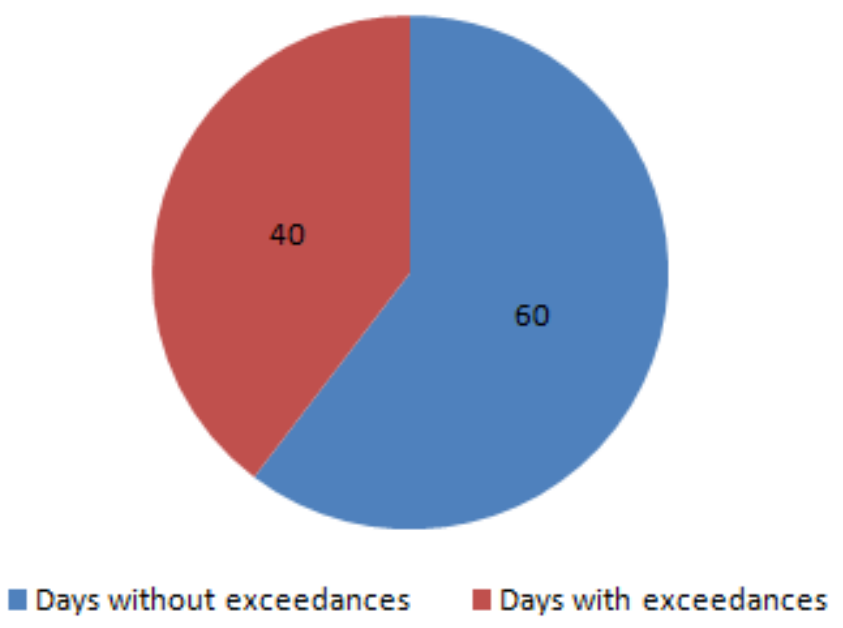

Figure 2. Percentage share of days with exceedances of permissible concentrations of PM10, as well as days without exceedances throughout the study period

It should be noted that, as required by law, the permissible annual number of days with exceeded permissible levels of airborne particulate matter is 35 (Official Journal of Laws 2012 item 1031), while in Sosnowiec only during the heating seasons in the years 2013, 2014, and 2015, the number of days exceeding the air quality standards was 106, 77 and 66, respectively, and thus far in excess of the permissible value of pollution (Fig. 3).

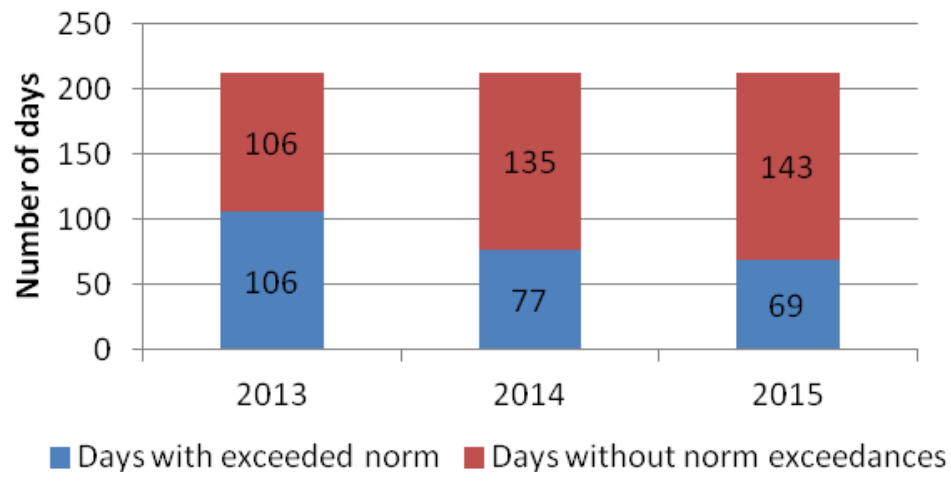

Figure 3. Number of days on which the permissible air quality norms were exceeded during the heating seasons between 2013-2015 in Sosnowiec

The concentration of airborne particulate matter in the city varies according to the type of atmospheric circulation (Knozová, 2012). The characteristics of the latter are often determined on the basis of the calendar of circulation types developed by Niedźwiedź, which distinguishes ten cyclonic situations, ten anticyclonic situations and one unidentified situation (Niedźwiedź, 1981).

In general, it can be concluded that higher concentrations are associated with anticyclonic situations (Leśniok et al., 2010, Bokwa, 2012). For the city of Sosnowiec, the mean concentration of PM10 particulate matter during anticyclonic conditions was 


$$
-1806-
$$

$55 \mu \mathrm{g} / \mathrm{m}^{3}$, whereas the mean concentration of this pollutant in the case of cyclonic conditions was $45 \mu \mathrm{g} / \mathrm{m}^{3}$ within the heating seasons of 2013-2015 (Table 1).

Table 1. Mean, minimum and maximum concentrations of PM10 particulate matter in Sosnowiec depending on the type of circulation in the heating seasons of 2013-2015 $\left(\mu \mathrm{g} / \mathrm{m}^{3}\right)$

\begin{tabular}{|c|c|c|c|c|}
\hline No. & Type of situation & Mean concentration & Minimum concentration & $\begin{array}{c}\text { Maximum } \\
\text { concentration }\end{array}$ \\
\hline 1 & $\mathrm{Na}$ & 33 & 16 & 76 \\
\hline 2 & $\mathrm{NEa}$ & 48 & 19 & 85 \\
\hline 3 & $\mathrm{Ea}$ & 56 & 24 & 225 \\
\hline 4 & SEa & 49 & 20 & 117 \\
\hline 5 & $\mathrm{Sa}$ & 69 & 39 & 148 \\
\hline 6 & SWa & 66 & 25 & 174 \\
\hline 7 & $\mathrm{Wa}$ & 49 & 16 & 126 \\
\hline 8 & NWa & 48 & 16 & 152 \\
\hline 9 & $\mathrm{Ca}$ & 63 & 17 & 123 \\
\hline 10 & $\mathrm{Ka}$ & 71 & 26 & 235 \\
\hline 11 & $\mathrm{Nc}$ & 32 & 10 & 73 \\
\hline 12 & $\mathrm{NEc}$ & 63 & 16 & 177 \\
\hline 13 & $\mathrm{Ec}$ & 43 & 17 & 81 \\
\hline 14 & $\mathrm{SEc}$ & 44 & 14 & 95 \\
\hline 15 & $\mathrm{Sc}$ & 53 & 23 & 88 \\
\hline 16 & SWc & 52 & 14 & 127 \\
\hline 17 & $\mathrm{Wc}$ & 35 & 12 & 136 \\
\hline 18 & NWc & 24 & 10 & 60 \\
\hline 19 & $\mathrm{Cc}$ & 56 & 56 & 56 \\
\hline 20 & $\mathrm{Bc}$ & 49 & 10 & 134 \\
\hline 21 & $\mathrm{x}$ & 57 & 28 & 93 \\
\hline & $\overline{\mathrm{x}}_{\mathrm{g}}$ & 55 & 22 & 146 \\
\hline & $\overline{\mathrm{x}}_{\mathrm{e}}$ & 45 & 18 & 102 \\
\hline & $\overline{\mathbf{x}}_{x}$ & 57 & 28 & 93 \\
\hline
\end{tabular}

Explanations: $N$ - north air advection; $N E$ - north-east air advection; $E$ - east air advection; SE - southeast air advection; $S$ - south air advection; $S W$ - south-west air advection; $W$ - west air advection; $N W$ - north-west air advection; $\mathrm{Cc}$ - central cyclonic conditions; $\mathrm{Ca}$ - central anticyclonic conditions; Ka anticyclonic wedge; Bc - cyclonic trough; $X$ - unidentified situation; A - anticyclonic conditions; $C$ cyclonic conditions

The highest concentrations of PM10 particulate matter in Sosnowiec during the heating season in the years 2013-2015 occurred during an anticyclonic wedge, on average amounting to $71 \mu \mathrm{g} / \mathrm{m}^{3}$. The minimum concentration for this type of anticyclonic situation was $26 \mu \mathrm{g} / \mathrm{m}^{3}$. The maximum concentration at the anticyclonic wedge was $235 \mu \mathrm{g} / \mathrm{m}^{3}$, which is a significant exceedance of $200 \mu \mathrm{g} / \mathrm{m}^{3}$. Above this level, there is a considerable risk to human health among particularly vulnerable groups of the population resulting from even a short-term exposure to pollution (Official Journal of Laws 2012 item 1031). In the case of anticyclonic advection from the south 
mean concentration was not much lower, at $69 \mu \mathrm{g} / \mathrm{m}^{3}$. In this case, the minimum concentration was $39 \mu \mathrm{g} / \mathrm{m}^{3}$, while the maximum was $148 \mu \mathrm{g} / \mathrm{m}^{3}$. A high mean concentration also occurred in the anticyclonic south-west air advection, amounting to $66 \mu \mathrm{g} / \mathrm{m}^{3}$. The minimum concentration for this type of situation was $25 \mu \mathrm{g} / \mathrm{m}^{3}$. The maximum concentration was higher than that of the anticyclonic advection from the south, as it amounted to $174 \mu \mathrm{g} / \mathrm{m}^{3}$. The occurrence of central anticyclonic conditions was associated with an average concentration of $63 \mu \mathrm{g} / \mathrm{m}^{3}$, which is also significantly over the permissible limit. The minimum concentration was $17 \mu \mathrm{g} / \mathrm{m}^{3}$, while the maximum reached $123 \mu \mathrm{g} / \mathrm{m}^{3}$. In this case, the minimum concentration was lower than the permissible PM10 level in the air. Although the mean concentration for the anticyclonic advection of air from the east was $56 \mu \mathrm{g} / \mathrm{m}^{3}$, which was significantly lower than the highest of the mean concentrations $\left(71 \mu \mathrm{g} / \mathrm{m}^{3}\right)$, the maximum concentration was as high as $225 \mu \mathrm{g} / \mathrm{m}^{3}$ reaching the highest level of all the situations. Anticyclonic conditions, such as north-east air advection, south-east air advection, west advection and north-west advection, shared very similar mean concentrations of $48-49 \mu \mathrm{g} / \mathrm{m}^{3}$, not exceeding the permissible level of PM10 concentrations. The maximum concentrations were in the range of $85-152 \mu \mathrm{g} / \mathrm{m}^{3}$. The lowest mean concentration of PM10 was noted during the anticyclonic advection of air from the north, at a level of $33 \mu \mathrm{g} / \mathrm{m}^{3}$. In this case the minimum concentration was $16 \mu \mathrm{g} / \mathrm{m}^{3}$, while the maximum was $76 \mu \mathrm{g} / \mathrm{m}^{3}$.

In the case of cyclonic conditions, the highest mean concentration of PM10 particulate matter in Sosnowiec during the heating seasons in the years 2013-2015 occurred during cyclonic advection from the north-east and amounted to $63 \mu \mathrm{g} / \mathrm{m}^{3}$. The minimum concentration was $16 \mu \mathrm{g} / \mathrm{m}^{3}$, i.e. not exceeding the permissible level, while the maximum concentration was $177 \mu \mathrm{g} / \mathrm{m}^{3}$. It should be noted that central cyclonic conditions occurred only once during the entire study period, so the relatively high concentration of $56 \mu \mathrm{g} / \mathrm{m}^{3}$ for this type of circulation cannot be taken into account in the analysis. The high value could have been accidental, which cannot be determined without more data. Other than the central cyclonic situation, advection from the south was associated with the second highest mean PM10 concentration of $53 \mu \mathrm{g} / \mathrm{m}^{3}$. The minimum concentration reached $23 \mu \mathrm{g} / \mathrm{m}^{3}$ and therefore it did not exceed the permissible level. The maximum concentration was $88 \mu \mathrm{g} / \mathrm{m}^{3}$. A slightly lower mean concentration of $52 \mu \mathrm{g} / \mathrm{m}^{3}$ was associated with cyclonic south-west air advection. The minimum concentration did not exceed the permissible level and was $14 \mu \mathrm{g} / \mathrm{m}^{3}$, while the maximum concentration was $127 \mu \mathrm{g} / \mathrm{m}^{3}$. A mean concentration just below the permissible level of $49 \mu \mathrm{g} / \mathrm{m}^{3}$ can be attributed to the cyclonic trough. It should be noted that the lowest of all the minimum concentrations of $10 \mu \mathrm{g} / \mathrm{m}^{3}$ was noted for this type of situation, reaching the same level only with the cyclonic north-west air advection. The maximum concentration was $134 \mu \mathrm{g} / \mathrm{m}^{3}$. Similar concentrations in the range of 43-44 $\mu \mathrm{g} / \mathrm{m}^{3}$ were associated with cyclonic advection of air from the east and south-east. The minimum concentrations were in the range of $14-17 \mu \mathrm{g} / \mathrm{m}^{3}$, while the maximum concentrations were $81-95 \mu \mathrm{g} / \mathrm{m}^{3}$. The mean concentrations during cyclonic advection from the north and cyclonic advection from the west ranged from 32 to $35 \mu \mathrm{g} / \mathrm{m}^{3}$. Minimum concentrations were $10-12 \mu \mathrm{g} / \mathrm{m}^{3}$, while maximum concentrations showed a greater variation, with values ranging between $73-136 \mu \mathrm{g} / \mathrm{m}^{3}$. The lowest mean concentration in cyclonic conditions occurred with the north-west air advection, amounting to only $24 \mu \mathrm{g} / \mathrm{m}^{3}$. This was at the same time the lowest average concentration among all types of cyclonic and anticyclonic conditions. The minimum concentration in this case was $10 \mu \mathrm{g} / \mathrm{m}^{3}$, which, as mentioned above, is also the lowest 
minimum concentration occurring during a cyclonic trough. The maximum concentration was $60 \mu \mathrm{g} / \mathrm{m}^{3}$ and was the lowest of all maxima, with the exception of the central cyclonic situation.

Unidentified situations were characterized by a mean PM10 concentration, remaining at a level of $57 \mu \mathrm{g} / \mathrm{m}^{3}$. The minimum concentration did not exceed the permissible level, reaching a value of $28 \mu \mathrm{g} / \mathrm{m}^{3}$. The highest recorded concentration for unidentified situations was $93 \mu \mathrm{g} / \mathrm{m}^{3}$.

It can be observed that higher concentrations of PM10 particulate matter in Sosnowiec are associated with anticyclonic conditions. The worst air quality with respect to PM10 particulate matter throughout the heating seasons of the 2013-2015 period occurred during anticyclonic conditions. Also, higher concentrations of pollutants are correlated with air inflow from the south, irrespective of the anticyclonic or cyclonic nature of the conditions. The mean concentration for advection from the south is approximately $55 \mu \mathrm{g} / \mathrm{m}^{3}$, compared to $41 \mu \mathrm{g} / \mathrm{m}^{3}$ for north advection. The mean particulate matter concentration for east advection is $51 \mu \mathrm{g} / \mathrm{m}^{3}$, while the mean concentration associated with advection from the west is $46 \mu \mathrm{g} / \mathrm{m}^{3}$. The average concentration of PM10 for the north-east advection is $46 \mu \mathrm{g} / \mathrm{m}^{3}$, while for the northwest advection it is $37 \mu \mathrm{g} / \mathrm{m}^{3}$. The mean concentration of PM10 in the south-east air advection is $53 \mu \mathrm{g} / \mathrm{m}^{3}$, and in the case of south-west advection, it is $54 \mu \mathrm{g} / \mathrm{m}^{3}$.

Another important issue in addition to the concentration occurring for a particular type of atmospheric circulation is the frequency of this situation. During the period considered, the prevalence of anticyclonic events was $54.72 \%$, while $43.24 \%$ of cases were cyclonic. Unidentified situations accounted for merely $2.04 \%$ of cases. During the days with exceeded permissible PM10 levels, the incidence rate was $66.51 \%$ for anticyclonic systems and $30.72 \%$ for cyclonic systems. The frequency of various atmospheric circulation types overall and during PM10 exceedances in the 2013-2015 heating seasons in Sosnowiec are presented in Table 2 below.

Table 2. Frequency of atmospheric circulation types during the occurrence of exceedances in the permissible levels of PM10 particulate matter in Sosnowiec during the 20132015heating seasons

\begin{tabular}{|c|c|c|c|c|c|c|c|c|c|}
\hline \multirow{3}{*}{$\stackrel{8}{z}$} & \multirow{3}{*}{ 专㞭 } & \multicolumn{8}{|c|}{ Frequency \% } \\
\hline & & \multicolumn{2}{|c|}{2013} & \multicolumn{2}{|c|}{2014} & \multicolumn{2}{|r|}{2015} & \multicolumn{2}{|c|}{ Average } \\
\hline & & Total & Exceedance & Total & Exceedance & Total & Exceedance & Total & Exceedance \\
\hline 1 & $\mathrm{Na}$ & 1.89 & 1.89 & 0.00 & 0.00 & 4.25 & 0.00 & 2.04 & 0.63 \\
\hline 2 & $N E a$ & 3.30 & 1.89 & 2.36 & 3.90 & 1.89 & 1.45 & 2.52 & 2.41 \\
\hline 3 & $E a$ & 4.25 & 3.77 & 7.08 & 5.19 & 3.30 & 4.35 & 4.87 & 4.44 \\
\hline 4 & $S E a$ & 5.19 & 6.60 & 11.32 & 7.79 & 8.49 & 8.70 & 8.33 & 7.70 \\
\hline 5 & $S a$ & 1.89 & 2.83 & 6.60 & 10.39 & 1.42 & 2.90 & 3.30 & 5.37 \\
\hline 6 & $S W a$ & 8.96 & 12.26 & 8.49 & 12.99 & 8.49 & 15.94 & 8.65 & 13.73 \\
\hline 7 & $W a$ & 9.91 & 10.38 & 4.25 & 6.49 & 19.81 & 20.29 & 11.32 & 12.39 \\
\hline 8 & $N W a$ & 5.66 & 4.72 & 1.42 & 2.60 & 4.72 & 2.90 & 3.93 & 3.40 \\
\hline 9 & $\mathrm{Ca}$ & 4.25 & 5.66 & 1.89 & 5.19 & 5.19 & 5.80 & 3.77 & 5.55 \\
\hline 10 & $K a$ & 4.25 & 7.55 & 6.13 & 9.09 & 7.55 & 15.94 & 5.97 & 10.86 \\
\hline 11 & $N c$ & 0.94 & 0.00 & 1.42 & 1.30 & 1.89 & 0.00 & 1.42 & 0.43 \\
\hline 12 & $N E c$ & 5.19 & 6.60 & 0.94 & 1.30 & 1.89 & 2.90 & 2.67 & 3.60 \\
\hline
\end{tabular}




\begin{tabular}{|c|c|c|c|c|c|c|c|c|c|}
\hline \multirow{3}{*}{$\stackrel{8}{z}$} & \multirow{3}{*}{ 呟 } & \multicolumn{8}{|c|}{ Frequency \% } \\
\hline & & \multicolumn{2}{|c|}{2013} & \multicolumn{2}{|c|}{2014} & \multicolumn{2}{|r|}{2015} & \multicolumn{2}{|c|}{ Average } \\
\hline & & Total & Exceedance & Total & Exceedance & Total & Exceedance & Total & Exceedance \\
\hline 13 & $E c$ & 5.19 & 6.60 & 3.30 & 1.30 & 2.36 & 0.00 & 3.62 & 2.63 \\
\hline 14 & $S E c$ & 6.60 & 4.72 & 8.96 & 2.60 & 2.36 & 0.00 & 5.97 & 2.44 \\
\hline 15 & $S c$ & 2.83 & 3.77 & 2.83 & 2.60 & 2.36 & 4.35 & 2.67 & 3.57 \\
\hline 16 & $S W c$ & 7.08 & 5.66 & 9.91 & 14.29 & 3.77 & 2.90 & 6.92 & 7.61 \\
\hline 17 & $W c$ & 8.02 & 0.94 & 6.60 & 1.30 & 6.13 & 2.90 & 6.92 & 1.71 \\
\hline 18 & $N W c$ & 4.72 & 0.94 & 4.72 & 0.00 & 3.77 & 0.00 & 4.40 & 0.31 \\
\hline 19 & $C c$ & 0.47 & 0.94 & 0.00 & 0.00 & 0.00 & 0.00 & 0.16 & 0.31 \\
\hline 20 & $B c$ & 7.55 & 9.43 & 9.91 & 9.09 & 8.02 & 5.80 & 8.49 & 8.11 \\
\hline 21 & $x$ & 1.89 & 2.83 & 1.89 & 2.60 & 2.36 & 2.90 & 2.04 & 2.78 \\
\hline & $\Sigma \mathrm{a}$ & 49.53 & 57.55 & 49.53 & 63.64 & 65.09 & 78.26 & 54.72 & 66.51 \\
\hline & $\Sigma \mathrm{c}$ & 48.58 & 39.62 & 48.58 & 33.77 & 32.55 & 18.84 & 43.24 & 30.72 \\
\hline & $\sum x$ & 1.89 & 2.83 & 1.89 & 2.60 & 2.36 & 2.90 & 2.04 & 2.78 \\
\hline
\end{tabular}

In the case of anticyclonic conditions, the most common type of atmospheric circulation in the heating 2013-2015 seasons in Sosnowiec was the west air advection, which averaged $11.32 \%$, while during the period of exceeded permissible levels of PM10 particulate matter, the incidence of this type of situation amounted to $12.39 \%$. It is worth noting that the anticyclonic advection from the west was the most common of all situations. The second most common in terms of the prevalence of anticyclonic conditions was the south-west advection, amounting to $8.65 \%$ of all situations. In the case of days with exceeded permissible PM10 levels, this situation reached a frequency of $13.75 \%$. Despite the fact that anticyclonic advection from the south-west is less frequent than advection from the west, its appearance is more frequently associated with exceeded permissible levels of PM10 in Sosnowiec. The third most frequently occurring type of anticyclonic conditions was the advection of air from the south-east, occurring in $8.33 \%$ and $7.70 \%$ of cases during days with excessive particulate matter pollution levels. The anticyclonic wedge associated with the highest mean concentrations of PM10 occurred only in $5.97 \%$ of cases, but for days with PM10 levels above the permissible level, the frequency of the anticyclonic wedge was at a level of $10.86 \%$. In spite of the moderate incidence of this situation, its occurrence is in many cases associated with the exceedance of permissible levels of particulate matter PM10. The lowest prevalence among anticyclonic conditions was observed in the case of north advection, occurring in $2.04 \%$ of cases. During days with PM10 levels exceeding the permissible limit, north advection was only $0.63 \%$.

In cyclonic conditions, the cyclonic trough proved to dominate, at $8.49 \%$ and $8.11 \%$ on average observed during the days when PM10 particulate matter levels were exceeded in the city. The second most common type of cyclonic conditions was the advection of south-west air, which averaged $6.92 \%$ and $7.61 \%$ on days with exceeded permissible PM10 levels. Equally frequently, cyclonic advection of air from the west amounted to $6.92 \%$, but during days with exceeded permissible levels of PM10 this situation occurred in only $1.71 \%$ of cases. Except for the central cyclonic situation, which occurred only once in the analysed period, the cyclonic north advection was least 
frequent at $1.42 \%$, and only $0.43 \%$ on days when permissible levels were exceeded. It should be noted that cyclonic advection from the north was the least common type of atmospheric circulation.

Unidentified situations accounted for only $2.04 \%$ of the total, and $2.78 \%$ of the days when permissible levels of PM10 in Sosnowiec were exceeded.

Interesting conclusions can be drawn from the analysis of the mutual relationship between mean concentrations and the frequency of incidence. For example, a high mean concentration of $69 \mu \mathrm{g} / \mathrm{m}^{3}$ is linked to anticyclonic advection from the south, but this situation occurs with a frequency of $3.30 \%$, which is not high. It could be interesting to attempt to assign particular types of atmospheric circulation to groups of hazards (Ziernicka-Wojtaszek, 2012). Permissible levels of PM10 concentrations of $50 \mu \mathrm{g} / \mathrm{m}^{3}$ and a median of the overall prevalence of $5.66 \%$ were chosen as parameters separating individual groups of hazards (Fig. 4).

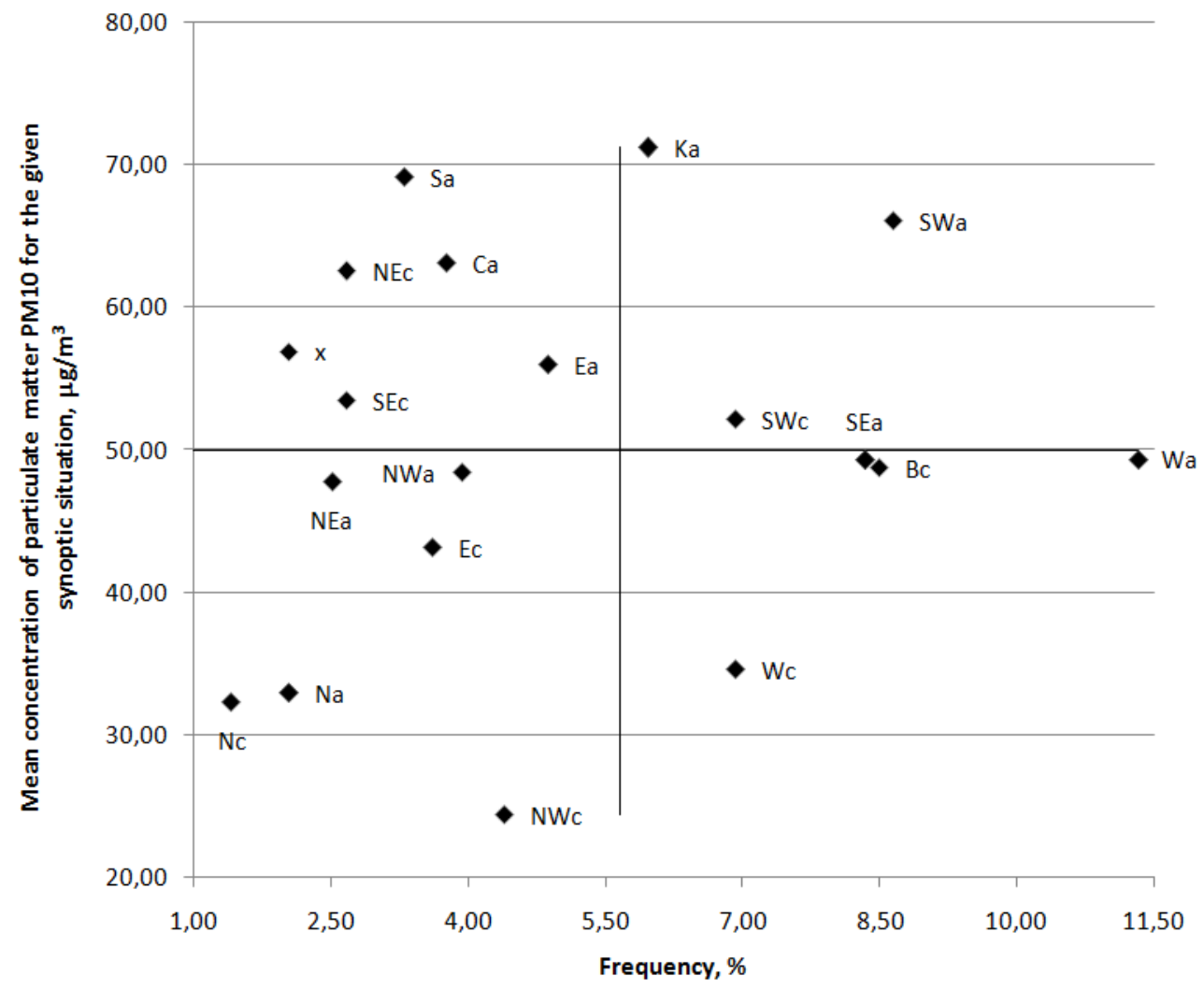

Figure 4. Circulation conditions for the mean concentrations of PM10 in the 2013-2015 heating seasons in Sosnowiec

These parameters can be divided into four groups. The first group, representing the greatest hazard, includes situations such as the anticyclonic wedge, the anticyclonic advection from the south-west and the cyclonic advection from the south-west. These situations are characterized by an average PM10 particulate matter concentration higher than the permissible level, and prevalence higher than 5.66\%. The second group, representing a high level of hazard, concerns situations with a mean concentration of more than $50 \mu \mathrm{g} / \mathrm{m}^{3}$ and a prevalence of less than $5.5 \%$. This includes unidentified situations, anticyclonic advections from the south, anticyclonic advections from the 
east, central anticyclonic situation, cyclonic advection from the south-east, and cyclonic advection from the north-east. The third group, representing a minor hazard, includes situations such as cyclonic and anticyclonic advection from the south-east, anticyclonic advection from the west and cyclonic advection from the west. These situations are characterized by a mean concentration of PM10 below the permissible level, and a prevalence of over $5.66 \%$. The above-mentioned situations comprise the fourth, low hazard group, characterized by an average concentration of PM10 below $50 \mu \mathrm{g} / \mathrm{m}^{3}$ and the lowest frequency.

\section{Discussion}

This paper analyses the effect of the type of circulation on the PM10 particulate matter concentration in the air in the city of Sosnowiec. The impact of meteorological conditions such as air temperature, wind force, or precipitation values, which also affect airborne concentrations of pollutants, has not been analysed (Czarnecka and Nidzgorska-Lencewicz, 2008). Exceeded permissible levels of pollution with PM10 particulate matter in Sosnowiec pose a serious environmental hazard. Permissible levels of airborne particulate matter were exceeded pollution on about $40 \%$ of days in the heating seasons between 2013 and 2015. In this area anticyclonic conditions dominate, representing $54.72 \%$ of all days in the studied period. This result is confirmed by scientific studies addressing the issue of air quality (Demuzere et al., 2009), whose authors concluded that anticyclonic conditions predominate over Europe, and thus also in Poland. In cities, air quality is associated with anticyclonic conditions, which is consistent with the results of this research (Bielec-Bąkowska et al., 2011). The most unfavourable group of situations includes the anticyclonic wedge, the anticyclonic advection from the south-west, and the cyclonic advection from the south-west. The maximum concentration of PM10, at a level of $235 \mu \mathrm{g} / \mathrm{m}^{3}$ occurred during the anticyclonic wedge. Anticyclonic advection from the north-west, anticyclonic advection from the north-east, anticyclonic advection from the north, cyclonic advection from the east, cyclonic advection from the north, and cyclonic advection from the north-west belong to the group associated with the lowest risk of PM10 exceeding the permissible level. Frequent exceedances of permissible levels are correlated with inflow of air from the south. A similar dependency occurs in other Polish cities (Leśniok and Caputa, 2009; Bokwa, 2012; Czarnecka and Nidzgorska-Lencewicz, 2015; Leśniok et al., 2010).

In the city of Sosnowiec and the Upper Silesia region, several studies have been conducted on the impact of synoptic conditions on PM10 concentrations from various periods in the past. Although the air quality in Sosnowiec and Upper Silesia is not satisfactory, there are positive trends in the reduction of pollutants due to excessive PM10 concentrations. Comparison of the results from 1994-2004 averaged from nine monitoring stations in Upper Silesia (Leśniok et al., 2010) with the results of this study for Sosnowiec from 2013-2015 shows that the mean PM10 concentrations are currently lower by $18 \mu \mathrm{g} / \mathrm{m}^{3}$ for anticyclonic conditions and by $9 \mu \mathrm{g} / \mathrm{m}^{3}$ for cyclonic conditions. For conditions where the concentrations are highest, i.e. SWa, the values are on average as much as $23 \mu \mathrm{g} / \mathrm{m}^{3}$ lower. The downward trend of PM10 concentration in the air in the Katowice region is illustrated by the results presented in the graphs for the 19942004 period (Leśniok and Caputa, 2009). The positive trend of reduction of air pollution by PM10 in Sosnowiec is confirmed by the results for the number of days when permissible levels were exceeded in the 2013-2015 heating seasons in Sosnowiec, 
presented in this paper. These values in successive years were 106, 77 and 69 days. For 2009 the number was 108 days (Bielec-Bąkowska et al., 2011). It is also worth noting that in previous research of this type concerning the dependence of PM10 concentrations on synoptic conditions, only the mean concentrations for various synoptic conditions were given. What is new in the present study is the simultaneous presentation of both the mean PM10 concentration for each synoptic situation and the frequency of these situations. Despite the downward trend in particulate air pollution due to air protection programmes, the variability of PM10 concentrations in different synoptic conditions is very high. Conditions generating high and excessive concentrations are particularly interesting. The results of this study and future research may be used to predict high concentrations and exceedances of permissible PM10 levels on the basis of forecasts of synoptic conditions.

\section{Conclusions}

The following conclusions can be drawn from the research:

1. Daily PM10 concentrations in the heating season vary a great deal depending on frequently changing synoptic conditions. Higher PM10 concentrations are associated with anticyclonic conditions, during which the PM10 concentration was $55 \mu \mathrm{g} / \mathrm{m}^{3}$, a compared to $45 \mu \mathrm{g} / \mathrm{m}^{3}$ for cyclonic conditions. During the heating seasons in Sosnowiec, anticyclonic conditions predominate, accounting for $54.7 \%$, and $66.5 \%$ on days when permissible PM10 levels were exceeded in the air.

2. The highest risk of exceeding the permissible levels of PM10 particulate matter in the city of Sosnowiec occurs in the anticyclonic wedge, but other hazardous situations include anticyclonic and cyclonic advection from the south-west. These situations are characterized by an average PM10concentration above the permissible level and a frequency of $5.66 \%$.

3. There is a downward trend in the PM10 concentration both during the research period and in comparison to periods in the years preceding it, studied by other authors.

4. The relationships observed can be used to predict high concentrations of PM10 and exceedances of permissible levels on the basis of forecasts of synoptic conditions.

Acknowledgments. The research was carried out under Project no. DS-3337/KEKiOP/2017 financed from a research grant allocated by the Ministry of Science and Higher Education.

\section{REFERENCES}

[1] Bielec-Bąkowska, Z., Knozová, G., Leśniok, M., Matuszko, D., Piotrowicz, K. (2011): High Suspended Dust Concentrations In Brno, Sosnowiec And Krakow (The Year 2009 As An Example). - Prace Geograficzne, 126, Instytut Geografii i Gospodarki Przestrzennej UJ, Kraków, 67-84. (in Polish)

[2] Bokwa, A. (2012): Zanieczyszczenie powietrza pyłem zawieszonym PM10 a sytuacje synoptyczne i warunki termiczne w Krakowie. - In: Bielec-Bąkowska., Z., Łupikasza, E., Widawski, A. (eds.) Rola cyrkulacji atmosfery w kształtowaniu klimatu. Kat. Klimat., Wydz. Nauk o Ziemi, Uniw. Śl., Sosnowiec: 275-286. (in Polish)

[3] Czarnecka, M., Kalbarczyk, R. (2008): Warunki meteorologiczne kształtujące zmienność stężenia pyłu zawieszonego na Pomorzu. - Acta Agrophysica 11(2): 357-368. (in Polish) 


$$
\text { - } 1813 \text { - }
$$

[4] Czarnecka, M., Nidzgorska-Lencewicz, J. (2008): Warunki meteorologiczne kształtujące jakość powietrza w Szczecinie w styczniu i lipcu w roku 2006. - Acta Agrophysica 12(1): 55-72. (in Polish)

[5] Czarnecka, M., Nidzgorska-Lencewicz, J. (2010): The influence of precipitation conditions on the concentration of suspended particulates PM10. - Meteorology and Climatology Research. (ed.) J. Leśny. Acta Agrophysica. Rozprawy i Monografie. 184: 132-147.

[6] Czarnecka, M., Nidzgorska-Lencewicz, J. (2015): Application of Cluster Analysis in Defining the Meteorological Conditions Shaping the Variability of PM10 Concentration. - Środkowo-Pomorskie Towarzystwo Naukowe Ochrony Środowiska, Rocznik Ochrona Środowiska 17: 40-61.

[7] Demuzere, M., Trigo, R. M., Vila-Guerau de Arellano, J., van Lipzig, N. P. M. (2009): The impact of weather and atmospheric circulation on O3 and PM10 levels at a rural midlatitude site. - Atmospheric Chemistry and Physics Discussions 9: 2695-2714.

[8] European Environment Agency. (2016): Air quality in Europe - 2016 report.

[9] Inspekcja Ochrony Środowiska Wojewódzkiego lnspektoratu Ochrony Środowiska w Katowicach. (2017): Piętnasta roczna ocena jakości powietrza w województwie Śląskim, obejmująca 2016 rok. - Wojewódzki Inspektorat Ochrony Środowiska w Katowicach. (in Polish)

[10] Knozová, G. (2012): Zanieczyszczenie pyłem zawieszonym na Morawach Południowych przy różnych typach cyrkulacji. - In: Bielec-Bąkowska., Z., Łupikasza, E., Widawski, A. (eds.) Rola cyrkulacji atmosfery w kształtowaniu klimatu. Kat. Klimat., Wydz. Nauk o Ziemi, Uniw. Śl., Sosnowiec: 287-297. (in Polish)

[11] Leśniok, M., Caputa, Z. (2009): The role of atmospheric circulation in air pollution distribution in Upper Silesia (Southern Poland). - International Journal of Environment and Waste Management, Special issue on: „Urban Air Pollution: Problems, Control Technologies and Management Practices" 4, 1/2: 62-74.

[12] Leśniok, M., Małarzewski, Ł., Niedźwiedź, T. (2010): Classification of circulation types for Southern Poland with an application to air pollution concentration in Upper Silesia. Physics and Chemistry of the Earth, Parts A/B/C, 35 (9-12), 516-522.

[13] Majewski, G. (2005): Zanieczyszczenie powietrza pyłem zawieszonym PM10 na Ursynowie i jego związek z warunkami meteorologicznymi. - Przegląd Naukowy Inżynieria i Kształtowanie Środowiska, Wydawnictwo SGGW, 14, 1(31): 210-223. (in Polish)

[14] Majewski, G. (2007): Wpływ warunków meteorologicznych na zanieczyszczenie powietrza pyłem zawieszonym w rejonie aglomeracji warszawskiej. - Praca doktorska. Wydział Inżynierii i Kształtowania Środowiska SGGW. (in Polish)

[15] Niedźwiedź, T. (1981): Sytuacje synoptyczne i ich wpływ na zróżnicowanie przestrzenne wybranych elementów klimatu w dorzeczu górnej Wisły. - Rozprawy Habilitacyjne UJ, 58.

[16] Official Journal of Laws 2012 item 1031: Rozporządzenie Ministra Środowiska z dnia 24 sierpnia 2012 r. w sprawie poziomów niektórych substancji w powietrzu (Dz.U. 2012 poz. 1031). (in Polish)

[17] Ziernicka-Wojtaszek, A. (2012): Cyrkulacyjne uwarunkowania susz rolniczych w województwie podkarpackim. - Infrastruktura i Ekologia Terenów Wiejskich, 2/III/2012, PAN, Oddział w Krakowie, 153-162. (in Polish) 